\title{
PENGARUH RETURN ON ASSET, EARNING PER SHARE DAN PRICE TO BOOK VALUE TERHADAP RETURN SAHAM PADA PT WASKITA KARYA, Tbk. PERIODE TAHUN 2010-2019
}

\author{
1Oktavianingsih, ${ }^{2 *}$ Adji Widodo \\ Universitas Pamulang, Tangerang Selatan, Banten, Indonesia \\ *dosen01554@unpam.ac.id
}

\begin{abstract}
Abstrak
Penelitian ini bertujuan untuk mengetahui pengaruh Return On Assets, Earning Per Share, dan Price to Book Value terhadap Return Saham pada PT Waskita Karya, Tbk. Periode Tahun 2010 - 2019. Variabel independen yang diteliti adalah Return On Assets $\left(\mathrm{X}_{1}\right)$, Earning Per Share $\left(\mathrm{X}_{2}\right)$ dan Price to Book Value $\left(\mathrm{X}_{3}\right)$ sedangkan variabel dependennya adalah Return Saham (Y). Metode penelitian yang digunakan adalah kuantitatif deskriptif menggunakan jenis data sekunder yang diperoleh dari Laporan Keuangan Publikasi PT Waskita Karya, Tbk. Periode Tahun 2010-2019. Teknik pengumpulan data menggunakan teknik Analisis Deskriptif, Uji Asumsi Klasik, Analisis Regresi Linier Sederhana, Analisis Regresi Linier Berganda, Uji Koefisien Determinasi, dan Uji Hipotesis. Hasil penelitian ini Hasil koefisien determinasi senilai 0,906 atau 90.6\% Pada Uji hipotesis dapat diketahui bahwa Ho4 ditolak dan $\mathrm{Ha}_{4}$ diterima, artinya terdapat pengaruh yang signifikan secara simultan Return On Assets (ROA), Earning Per Share (EPS), dan Price to Book Value (PBV) terhadap Return Saham.
\end{abstract}

Kata Kunci: Return On Assets, Earning Per Share, Price to Book Value, Return Saham

Abstract

This research aims to find out the effect of Return On Assets, Earning Per Share, and Price to Book Value on Stock Return on PT Waskita Karya, Tbk. Period of 2010 - 2019. The independent variables studied were Return On Assets (X1), Earning Per Share (X2) and Price to Book Value (X3) while the dependent variables were Stock Return (Y). The research method used is quantitative descriptive using secondary data types obtained from the Publication Financial Statements of PT Waskita Karya, Tbk. Period 2010-2019. Data collection techniques use Descriptive Analysis techniques, Classical Assumption Tests, Simple Linear Regression Analysis, Multiple Linear Regression Analysis, Determination Coefficient Tests, and Hypothesis Tests. The results of the coefficient of determination worth 0.906 or $90.6 \%$ on the hypothesis test can be known that Ho4 was rejected and Ha4 accepted, meaning there is a significant influence simultaneously Return On Assets (ROA), Earning Per Share (EPS), and Price to Book Value (PBV) to Stock Return

Keyword: Return On Assets, Earning Per Share, Price to Book Value, Stock Return

\section{PENDAHULUAN}

Perkembangan pasar modal di Indonesia pada saat ini semakin besar. Dalam kegiatannya pasar modal dapat dikatakan sebagai media atau tempat dimana pembeli dan penjual bisa bertransaksi pada pertukaran suatu komoditas atau kelompok komoditas, dan komoditas yang diperjual-belikan tersebut yaitu modal. Menurut Undang-Undang No. 25 Tahun 2007, pengertian pasar modal adalah suatu kegiatan yang bersangkutan dengan penawaran umum dan perdagangan efek. Pasar modal memberikan peranan penting di bidang ekonomi, yaitu memberikan kesempatan bagi pihak yang memiliki kelebihan dananya (investor) untuk menginvestasikan dananya agar memperoleh manfaat atau tingkat pengembalian di masa mendatang dan sebaliknya memberikan kemudahan bagi pihak yang kekurangan dana (perusahaan) untuk memperoleh dana. 
Investor akan berinvestasi pada perusahaan yang memiliki arus kas yang baik, sehingga dapat dikatakan bahwa informasi arus kas merupakan informasi penting yang dibutuhkan investor untuk mengetahui kemampuan perusahaan dalam menghasilkan kas bagi investor, maupun untuk membayar kewajiban perusahaan serta kegiatan operasional perusahaan. Bagi para investor mengambil keputusan investasi saham harus didahului dengan proses analisis terhadap faktorfaktor yang diperkirakan akan mempengaruhi Return Saham. Analisis tersebut adalah analisis teknikal dan fundamental. Menurut Tandelilin (2010:392) yang dimaksud dengan analisis teknikal adalah teknik untuk memprediksi arah pergerakan harga saham dan indikator pasar saham lainnya berdasarkan pada data historis seperti informasi harga. Sedangkan analisis fundamental memberi petunjuk akan kemampuan perusahaan menghasilkan laba dimasa depan yang dapat dilihat dari harga sahamnya dan mempelajari fakta ekonomi serta data historis keuangan suatu perusahaan.

Laba perusahaan selain merupakan salah satu indikator kemampuan perusahaan memenuhi kewajiban bagi para pemilik dana, juga merupakan elemen penting dalam penciptaan nilai perusahaan yang menunjukkan prospek perusahaan di masa yang akan datang. Menurut Tandelilin (2010:102) Return merupakan salah satu faktor yang memotivasi investor berinteraksi dan juga merupakan imbalan atas keberanian investor dalam menanggung risiko atas investasi yang dilakukannya. Tandelilin (2010:102) menyatakan sumber-sumber return investasi terdiri dari dua komponen utama, yaitu yield dan capital gain. Yield merupakan komponen return yang mencerminkan aliran kas atau pendapatan yang diperoleh secara periodik dari suatu investasi. Jika investor membeli saham, yield ditunjukkan oleh besarnya dividen, sedangkan capital gain merupakan kenaikan atau penurunan harga suatu saham yang bisa memberikan keuntungan atau kerugian bagi investor. Fluktuasi harga saham yang tinggi dan dividen yang tidak selalu dibayarkan oleh emiten menyebabkan adanya fluktuasi return atas saham.

Dari latar belakang masalah yang telah diuraikan tersebut di atas, penulis mencoba untuk menilai seberapa besar pengaruh Return On Assets, Earning Per Share, dan Price to Book Value terhadap Return Saham sebagai bahan dalam penelitian tugas skripsi yang berjudul "Pengaruh Return On Assets, Earning Per Share, dan Price to Book Value terhadap Return Saham pada PT Waskita Karya, Tbk.".

\section{METODOLOGI}

Penelitian ini merupakan penelitian deskriptif dengan pendekatan kuantitatif. Pendekatan ini berdasar dari kerangka teori, gagasan ahli, pemahaman peneliti berdasarkan pengalamannya, dikembangkan menjadi permasalahan dan pemecahannya yang diajukan untuk memperoleh pembenaran (verifikasi) dalam bentuk dukungan data empiris di lapangan.

\section{HASIL PENELITIAN DAN PEMBAHASAN}

a. Uji t (Parsial)

Uji t dalam penelitian ini dilakukan untuk mengetahui apakah variabel Return On Assets (ROA), Earning Per Share (EPS) dan Price to Book Value (PBV) secara parsial berpengaruh terhadap Return Saham.

Uji t dilakukan untuk mengetahui besaran signifikan variabel dengan cara membandingkan $t_{\text {hitung }}$ dengan $t_{\text {tabel. }}$ Rumus mencari $\mathrm{t}$ tabel yaitu sebagai berikut :

$\mathrm{T}$ tabel $=\mathrm{a}: 2 ; \mathrm{n}-\mathrm{k}-1$

$\mathrm{T}$ tabel $=(0.5: 2) ;(10-3-1)$

$\mathrm{T}$ tabel $=0.025 ; 6$

$\mathrm{T}$ tabel $=2.44691$

Berikut hasil uji $t$ menggunakan SPSS versi 26 : 
Tabel 1. Hasil Uji t

Coefficients ${ }^{a}$

\begin{tabular}{l|l|l|l} 
Unstandardized Coefficients & Standardized Coefficients & $\mathrm{t}$ & Sig.
\end{tabular}

\begin{tabular}{lr|r|r|r|r|} 
Model & \multicolumn{1}{c|}{ B } & Std. Error & Beta & & \\
\hline 1 (Constant) & -60.300 & 37.144 & & -1.623 & .156 \\
\hline ROA & -14.495 & 11.593 & -.171 & -1.250 & .258 \\
\hline EPS & .014 & .004 & .599 & 3.791 & .009 \\
\hline PBV & 72.360 & 9.878 & 1.231 & 7.325 & .000 \\
\hline
\end{tabular}

a. Dependent Variable: RETURN SAHAM

Sumber: Data olahan dari SPSS 26

Berdasarkan hasil perhitungan SPSS pada tabel diatas maka dapat disimpulkan :

a) Return On Assets (ROA) terhadap Return Saham

Dari table diperoleh $t_{\text {hitung }}$ sebesar -1.250 , nilai signifikan sebesar 0.258 dan $t_{\text {tabel }}$ 2.44691. Dari hasil tersebut dapat diketahui nilai $t_{\text {hitung }}<$ $t_{\text {tabel }}$ yaitu $-1.250<2.44691$ dan nilai signifikan > 0,05 yaitu $0.258>0,05$. Maka disimpulkan Ha ditolak dan Ho diterima, artinya Return On Assets (ROA) tidak berpengaruh signifikan terhadap Return Saham.

b) Earning Per Share (EPS) terhadap Return Saham

Berdasarkan tabel diperoleh $t_{\text {hitung }} 3.791$, nilai signifikan 0.009 dan $t_{\text {tabel }}$ 2.44691. Sehingga diperoleh $t_{\text {hitung }}$ $>t_{\text {tabel }}$ yaitu $3.791>2.44691$ dan nilai signifikansi $<0.05$ yaitu $0.009<0.05$. Maka dapat disimpulkan Ho ditolak dan Ha diterima artinya Earning Per Share (EPS) berpengaruh signifikan terhadap Return Saham.

c) Price to Book Value (PBV) terhadap Return Saham

Berdasarkan tabel diperoleh $t_{\text {hitung }} 7.325$, nilai signifikan 0.000 dan $t_{\text {tabel }}$ 2.44691. Sehingga diperoleh $t_{\text {hitung }}$ $>t_{\text {tabel }}$ yaitu $7.325>2.44691$ dan nilai signifikansi $<0.05$ yaitu $0.000<0.05$. Maka dapat disimpulkan Ho ditolak dan Ha diterima artinya Price to Book Value (PBV) berpengaruh signifikan terhadap Return Saham.

\section{b. Uji f (simultan)}

Uji f secara simultan dilakukan untuk mengetahui pengaruh Return On Assets (ROA), Earning Per Share (EPS) dan
Price to Book Value (PBV) secara simultan terhadap Return Saham. Untuk penilaian uji $f$ dengan membandingkan $f_{\text {hitung }}$ dan $f_{\text {tabel }}$ dengan kriteria sebagai berikut:

a) Jika $F_{\text {hitung }}>F_{\text {tabel }}$ maka hipotesis nol (Ho) ditolak dan hipotesis alternatif (Ha) diterima.

b) Jika $F_{\text {hitung }}<F_{\text {tabel }}$ maka hipotesis nol (Ho) diterima dan hipotesis alternatif (Ha) ditolak.

$$
\begin{aligned}
\mathrm{F}_{\text {tabel }} & =\mathrm{k} ;(\mathrm{n}-\mathrm{k}) \\
& =3 ;(10-3) \\
& =3 ; 7 \\
& =4.35
\end{aligned}
$$

Hasil penelitian Uji f menggunakan SPSS versi 26 sebagai berikut :

Tabel 2. Hasil Uji f

ANOVA $^{a}$

\begin{tabular}{cll|l|l|l|l} 
& $\begin{array}{l}\text { Sum of } \\
\text { Model }\end{array}$ & d & Mean & & \\
\hline S Regressi & 57764.2 & f & Square & F & Sig. \\
\hline $\begin{array}{l}\text { on } \\
45\end{array}$ & & 48254.7 & 19.28 & .002 \\
Residual & $\begin{array}{l}5989.62 \\
4\end{array}$ & 6 & 998.271 & & \\
\hline Total & $\begin{array}{l}63753.8 \\
69\end{array}$ & 9 & & & \\
\hline
\end{tabular}

a. Dependent Variable: RETURN SAHAM

b. Predictors: (Constant), PBV, ROA, EPS

Sumber: Data olahan dari SPSS 26

Berdasarkan tabel diatas Uji f dapat diketahui nilai $\mathrm{f}_{\text {hitung }}=19.288$ dan nilai signifikan 0,002 sehingga diperoleh $\mathrm{f}_{\text {hitung }}>\mathrm{f}_{\text {tabel }}$ yaitu $19.288>4,35$ dan nilai signifikan < 0,05 yaitu 0,002 < 0,05 maka Ho ditolak dan Ha diterima. Artinya Return On Assets (ROA), Earning Per Share (EPS) dan Price to Book Value (PBV) secara simultan berpengaruh signifikan terhadap Return Saham. 


\section{PEMBAHASAN PENELITIAN}

1. Pengaruh Return On Assets (ROA) terhadap Return Saham

Berdasarkan hasil penelitian perhitungan menggunakan uji $\mathrm{t}$ secara parsial pada tabel diperoleh thitung sebesar -1.250, nilai signifikan sebesar 0.258 dan tabel 2.44691. Dari hasil tersebut dapat diketahui Return On Assets (ROA) tidak berpengaruh signifikan terhadap Return Saham pada PT Waskita Karya, Tbk. Tidak signifikannya variabel Return On Assets (ROA) kemungkinan disebabkan karena banyaknya asset perusahaan yang menganggur, investasi dalam persediaan yang terlalu banyak, kelebihan uang kertas, aktiva tetap beroperasi dibawah normal dan lain-lain. Hal ini sesuai dengan penelitian sebelumnya yang dilakukan oleh Novita Supriantikasari (2019) yang menyatakan bahwa Return On Assets (ROA) tidak berpengaruh terhadap Return Saham.

2. Pengaruh Earning Per Share (EPS) terhadap Return Saham

Berdasarkan hasil penelitian perhitungan menggunakan uji $\mathrm{t}$ secara parsial pada tabel diperoleh $t_{\text {hitung }} 3.791$, nilai signifikan 0.009 dan $t_{\text {tabel }} 2.44691$. Dari hasil tersebut dapat diketahui Earning Per Share (EPS) berpengaruh positif signifikan terhadap Return Saham. Yang berarti apabila terjadi kenaikan pada Earning Per Share (EPS) maka Return Saham juga akan mengalami kenaikan. Hal ini terjadi kemungkinan karena naiknya laba yang dihasilkan perusahaan. Saat laba bersih naik sedangkan jumlah lembar saham yang beredar tetap, maka nilai EPS akan naik. Nilai EPS yang tinggi menunjukan bahwa perusahaan mampu mendistribusikan pendapatannya kepada pemegang saham dengan baik sehingga pengembalian yang akan diterima investor juga tinggi. Hal ini sesuai dengan penelitian sebelumnya yang dilakukan oleh Ratna Handayati dan Noer Rafikah Zulyanti (2018) yang menyatakan bahwa Earning Per Share
(EPS) berpengaruh signifikan terhadap Return Saham.

3. Pengaruh Price to Book Value (PBV) terhadap Return Saham

Berdasarkan hasil penelitian perhitungan menggunakan uji $\mathrm{t}$ secara parsial pada tabel diperoleh $t_{\text {hitung }} 7.325$, nilai signifikan 0.000 dan $t_{\text {tabel }} 2.44691$. Dari hasil tersebut dapat diketahui Price to Book Value (PBV) berpengaruh positif signifikan terhadap Return Saham. Yang berarti apabila terjadi kenaikan pada Price to Book Value (PBV) maka Return Saham juga akan mengalami kenaikan. Semakin tinggi PBV perusahaan, menandakan perusahaan memiliki nilai tambah yang mampu meningkatkan permintaan investor atas saham tersebut, sehingga harga saat dibeli cenderung lebih rendah dibanding harga sekarang. Perbedaan antara harga jual dengan harga beli inilah yang meningkatkan Return Saham. Hal ini sesuai dengan penelitian sebelumnya yang dilakukan oleh Mochammad Ridwan Ristyawan (2019) yang menyatakan bahwa Price to Book Value (PBV) berpengaruh signifikan terhadap Return Saham.

4. Pengaruh Return On Assets (ROA), Earning Per Share (EPS) dan Price to Book Value (PBV) secara simultan terhadap Return Saham.

Berdasarkan hasil penelitian dan perhitungan mengenai pengaruh Return On Assets (ROA), Earning Per Share (EPS) dan Price to Book Value (PBV) secara simultan terhadap Return Saham diperoleh hasil senilai 0,906 atau $90.6 \%$ sedangkan sisanya senilai $9.4 \%$ dipengaruhi oleh variabel lain yang tidak diteliti.

\section{KESIMPULAN DAN SARAN Kesimpulan}

Berdasarkan analisis penelitian data dan pembahasan yang telah dilakukan peneliti mengenai Return On Assets (ROA), Earning Per Share (EPS) dan Price to Book Value (PBV) terhadap Return Saham. Maka peneliti menarik kesimpulan sebagai berikut : 
1. Return On Assets (ROA) tidak berpengaruh signifikan terhadap Return Saham pada PT Waskita Karya, Tbk. selama periode tahun 2010-2019. Artinya jika laba perusahaan meningkat maka tidak mempengaruhi bersarnya Return Saham yang diperoleh pemilik saham.

2. Earning Per Share (EPS) berpengaruh signifikan terhadap Return Saham pada PT Waskita Karya, Tbk. selama periode tahun 2010-2019. Artinya jika nilai Earning Per Share (EPS) naik, maka Return Saham yang diperoleh pemilik saham pun akan meningkat.

3. Price to Book Value (PBV) berpengaruh signifikan terhadap Return Saham pada PT Waskita Karya, Tbk. selama periode tahun 2010-2019. Artinya jika nilai Price to Book Value (PBV) naik, maka akan meningkatkan Return Saham bagi pemilik saham.

4. Return On Assets (ROA), Earning Per Share (EPS) dan Price to Book Value (PBV) secara simultan berpengaruh signifikan terhadap Return Saham pada PT Waskita Karya, Tbk. selama periode tahun 20102019. Artinya jika nilai Return On Assets (ROA), Earning Per Share (EPS) dan Price to Book Value (PBV) mengalami kenaikan, maka akan meningkatkan nilai Return Saham yang akan diterima pemilik saham.

\section{Saran}

Berdasarkan hasil penelitian dan kesimpulan terkait pengaruh Return On Assets (ROA), Earning Per Share (EPS) dan Price to Book Value (PBV) terhadap Return Saham yang telah disampaikan pada penelitian ini, diharapkan mampu memberikan informasi bagi pihak yang berkepentingan antara lain:

1. Bagi peneliti selanjutnya disarankan untuk mengembangkan penelitian dengan menambah jumlah sampel penelitian sehingga dapat diperoleh hasil yang lebih akurat dan bervariasi.

2. Bagi perusahaan, seharusnya jika laba perusahaan besar maka Return Saham meningkat. Ternyata laba yang didapat tidak mempengaruhi Return Saham, maka perusahaan perlu evaluasi. Kenaikan laba kurang bisa menjadi ketertarikan untuk investor menanam saham di perusahaan tersebut.

3. Bagi investor hendaknya mempertimbangkan tingkat profitabilitas perusahaan karena akan mempengaruhi laba yang dihasilkan oleh perusahaan tersebut. Hal ini berkenaan dengan besaran keuntungan (Return Saham) yang kemudian akan dibagikan kepada pemegang saham.

\section{DAFTAR PUSTAKA}

Afandi, P. (2018). Manajemen Sumber Daya Manusia (Teori, Konsep dan Indikator). Riau: Zanafa Publishing.

Appley A. Lawrence, Lee, Oey, Liang. 2010. Pengantar Manajemen. Jakarta : Salemba Empat.

Brigham, Eugene F. dan Joel F. Houston. 2014. Dasar-dasar Manajemen Keuangan. Buku 1. Edisi 11. Jakarta : Salemba Empat.

D. Agus Harjito dan Martono. 2012. Manajemen Keuangan. Yogyakarta : Ekonisia.

Darmaji, Tjiptono dan Fakhruddin, Hendy M. 2012. Pasar Modal di Indonesia. Pendekatan Tanya Jawab. Jakarta : Salemba Empat.

Fahmi, Irham. (2016). Pengantar Manajemen Keuangan. Bandung : Alfabeta, CV.

Fahmi, Irham. 2012. Analisis Laporan Keuangan. Cetakan Ke-2. Bandung : Alfabeta.

Ghozali, Imam. 2011. Aplikasi Multivariate dengan Program IBM SPSS 19. Semarang : Badan Penerbit Universitas Diponegoro.

Handoko, T. Hani. 2011. Manajemen Personalia dan Sumberdaya Manusia. Yogyakarta: Penerbit BPFE.

Haque, M. G., et al. (2021). Micro Financial Sharia Non-bank Strategic Analysis: a Study at BMT Beringharjo, Yogyakarta. Budapest International Research and Critics Institute (BIRCIJournal): Humanities and Social Sciences, 4(2), 1677-1686 
Hasibuan, Malayu S.P. (2018). Fungsi Manajemen dan Unsur Manajemen. Jakarta: PT Bumi Aksara

Jogiyanto, Hartono. 2013. Teori Portofolio dan Analisis Investasi. Edisi Kedelapan. Yogyakarta : BPFE.

Jones, Charles P. 2014. Invesment Analysis and Management. New York. John Wiley and Sons.

Kasmir. (2017). Analisis Laporan Keuangan. Jakarta: PT Raja Grafindo Persada.

Kasmir. 2012. Analisis Laporan Keuangan. Jakarta : PT Raja Grafindo Persada.

Kasmir. 2014. Analisis Laporan Keuangan. Edisi Satu, Cetakan Ketujuh. Jakarta : Raja Grafindo Persada.

Musthafa. (2017). Manajemen Keuangan.Yogyakarta : Andi.

Noryani, Y. B. G., et al. (2020). Did ISO 45001, ISO 22000, ISO 14001 and ISO 9001 Influence Financial Performance? Evidence from Indonesian Industries. PalArch's Journal of Archaeology of Egypt/Egyptology, 17(7), 6930-6950.

Priyatno, Duwi. 2013. Mandiri Belajar Analisa Data dengan SPSS. Jakarta : Media Kom.

Pujiati, H., et al. (2021). Effect of ISO 9001: 2015 Quality Management Implementation in Education on School Performance. Journal of Contemporary Issues in Business and Government, 27(1), 1848-1855.

Putra, IGS., (2021). The Effect Of MacroEconomic Indicators On Share Prices In The Construction Sub-Sector And Building Companies Listed In Indonesia Stock Exchange 2013-2018. Turkish Journal of Computer and Mathematics Education (TURCOMAT). 12(9) 107-113
Sartono, Agus. 2010. Manajemen Keuangan Teori dan Aplikasi. Yogyakarta : BPFE.

Sedarmayanti dan Hidayat, Syarifudin. 2011. Metodologi Penelitian. Bandung : Mandar Maju.

Siswandi. 2011. Aplikasi Manajemen Perusahaan. Bogor : Mitra Wacana Media.

Sugiyono. 2010. Metode Penelitian Pendidikan Pendekatan Kuantitatif, Kualitatif, dan $R \mathcal{E D}$. Bandung : Alfabeta.

Sugiyono. 2012. Metode Penelitian Kuantitatif, Kualitatif, dan RED. Bandung : Alfabeta.

Sugiyono. 2013. Statistika untuk Penelitian. Bandung: Alfabeta.

Sugiyono. 2014. Metode Penelitian Kuantitatif Kualitatif dan RED. Bandung : Alfabeta.

Sugiyono. 2016. Metode Penelitian Kuantitatif Kualitatif dan RED. Bandung : Alfabeta.

Suhartono, A., et al. (2019). Pengaruh Earning Per Share Dan Return On Asset Terhadap Harga Saham Pada PT. Bank Negara Indonesia Tbk Periode 2009-2018. Jurnal Manajemen, Bisnis dan Organisasi (JUMBO), 3(3), 182-194.

Tandelilin, Eduardus. 2010. Portofolio dan Investasi : Teori dan Aplikasi. Yogyakarta : Kanisius.

http://e-resources.perpusnas.go.id

http://eprints.unpam.ac.id/4641/

http://eprints.unpam.ac.id/5731/

http://eprints.mercubuana-yogya.ac.id

http://eprints.ums.ac.id

wwww.idx.co.id

http://jurnal.unpand.ac.id

https://ojs.unud.ac.id

https://scholar.google.com

www.waskita.co.id 